\title{
Association between high serum total IgE levels and D11S97 on chromosome 11q13 in Japanese subjects
}

\author{
N Hizawa, E Yamaguchi, K Furuya, N Ohnuma, N Kodama, J Kojima, M Ohe, \\ Y Kawakami
}

\begin{abstract}
The genetic linkage of atopy to chromosome $11 \mathrm{q} 13$ through maternally derived alleles has been previously reported. Linkage analysis in Japanese families did not confirm the existence of a major gene for atopy at this locus under the model of autosomal dominant inheritance. However, we observed a significant association between serum total IgE levels and genetic markers at this locus both in 14 Japanese atopic families and in 120 unrelated Japanese subjects. We detected eight alleles at the D11S97 locus and eight alleles in the CA/GT repeat region in the fifth intron of the FcERIB gene. A significantly increased frequency of the D11S97/PstI $0.96 \mathrm{~kb}$ allele was observed in the chromosomes of the subjects with high serum total IgE levels both in the family study $(p<0.001)$ and in the population study $(p<0 \cdot 05)$. However, multipoint linkage analysis again did not show any evidence for the existence of a major gene regulating atopy on chromosome 11 q13 with location scores to -35 under the model of maternal inheritance. Evidence against linkage was confirmed by the non-parametric linkage analysis, using the affected pedigree member method. Also, there was no substitution of isoleucine for leucine in the fourth transmembrane domain of FceRI (Leu181), which was reported to be responsible for a subset of atopy in the British population. Therefore, the association of serum total IgE levels with chromosome 11 q13 indicates that a gene or genes at this locus may contribute to the expression of high IgE levels in the Japanese population as well as in the British population, but the heterogeneity of the genetic regulation of serum total IgE levels is evident between the two populations.
\end{abstract}

( $(\mathcal{M}$ Med Genet 1995;32:363-369)

The genetic components of atopy are complex. Although genes within the human major histocompatibility complex (MHC) on chromosome 6 are known to contribute to susceptibility, they alone are not sufficient to account for the complete genetic contribution to atopy. ${ }^{1}$ In 1989 , a linkage study performed by Cookson et $a l^{2}$ showed the presence of a single major autosomal dominant atopy gene linked to a marker on chromosome $11 \mathrm{q} 13$ by using a broad definition of atopy, namely any or all of a positive skin test, or a high antigen specific IgE value, or a high total IgE level. Although we tried to confirm this finding, linkage between chromosome 11q13 and atopy was not found in four atopic Japanese families with a lod score of less than -2.0 with a recombination fraction of $0 \cdot 15 .^{3}$ The attempts of several other groups to replicate the linkage have also not met with success. ${ }^{4-6}$ Moreover, Marsh et al reported evidence for linkage of genetic markers on chromosome 5q31, including the interleukin-4 gene (IL-4), with a gene controlling total serum IgE concentration.

However, the Oxford group reported that the atopy gene was active only when it was inherited from the maternal side, and that the gene encoding the $\beta$ subunit of the high affinity receptor for IgE (FcERI $\beta$ ) was the candidate gene on chromosome $11 \mathrm{q} 13 .{ }^{89}$ They also reported a variant sequence in which a leucine was substituted for an isoleucine at position 181 (Leu 181) in the fourth transmembrane domain of this receptor protein, and a significant association between the substitution and atopy. ${ }^{10}$

In order to clarify the differences in genetic regulation of atopic responses between the Japanese and British populations, we examined 10 new atopic families, in addition to the previous four families, and 120 unrelated subjects. Firstly, we analysed the linkage between atopy and markers on chromosome $11 \mathrm{q} 13$, taking into account the maternal inheritance of atopy in 14 families. Although we failed to confirm linkage of atopy to this locus, ${ }^{3}$ the maximum likelihood method we used detected significant linkage only if a gene or genes of major effect were segregating in the study families, ${ }^{11}$ and this method may be limited by both theoretical and practical problems in complex diseases. ${ }^{12}$ Non-parametric linkage studies such as the affected sib pair method or affected pedigree member method ${ }^{1314}$ may identify the presence of a candidate gene for atopy without any precise specification of the genetic models. Therefore, in this study, we also applied the affected pedigree member method of Weeks and Lange to our family data.

The association study offered an easy way of studying a genetic contribution to some complex diseases and proved to be useful for detecting the susceptibility gene, even if the contribution of this gene is not major. ${ }^{15}$ Therefore, we analysed the association of atopy with 
the D11S97 locus and the FceRI $\beta$ locus on chromosome $11 \mathrm{q} 13$ in 14 Japanese families. As we could detect a significant association between serum total IgE levels and the D11S97 locus, this association was further evaluated in 120 unrelated Japanese subjects, because the association found in the family study was not conclusive as relatives may share alleles by virtue of their family relationship.

Finally, we evaluated the prevalence of the Leu181 substitution in Japanese subjects.

\section{Materials and methods \\ SUBJECTS}

We recruited seven three generation families and seven nuclear families (107 family members in total) through atopic asthmatic probands, who were referred to our outpatient department. There was no connection between these 14 asthmatic families. The pedigrees studied are illustrated in fig 1 . The average age of the 107 family members was 37.6 years and ranged from 6 to 80 years. We also recruited 69 unrelated Japanese subjects referred to our outpatient department including 63 cases of bronchial asthma, three cases of chronic eczema, and three cases of pollinosis. No subjects were receiving systemic glucocorticoids for the treatment of asthma or any other diseases. We also studied 51 unrelated volunteers without symptoms of bronchial asthma, pollinosis, or eczema. In a population study, the subjects were selected on the basis of serum total IgE levels for comparison of this phenotype between subjects with and without the D11S97/ PstI $0.96 \mathrm{~kb}$ allele. The average age of the subjects in the population study was 41.5 years and ranged from 10 to 81 years. All subjects examined in both the family and the population study resided in Sapporo, Japan.

\section{ANALYSIS OF PHENOTYPE}

All subjects were assessed for skin prick test reactivity using 24 aqueous allergen extracts, such as house dust mite, grass and tree pollens, common moulds, animal danders, and negative controls (Torii Pharmaceutical Co, Tokyo, Japan). The response was read after 15 minutes. When the diameter of the erythema was larger than or equal to $15 \mathrm{~mm}$, or was larger than or equal to twice the diameter of the negative control, the response was considered to be positive. Total serum IgE levels were estimated by a radioimmunosorbent test (IgE RIST), and antigen specific IgE values which consisted of 16 inhalant antigens included in the array of the skin prick tests were measured by multiple antigen simultaneous tests (IgE MAST).$^{16}$

The atopic phenotype was determined as the presence of a positive skin test or a high total IgE level (above $300 \mathrm{IU} / \mathrm{ml}$, that is more than 2 SD above the geometric mean for the normal Japanese population) or a high antigen specific IgE value (MAST $>=0.67 \mathrm{VOLT}$ ). In addition, atopy was alternatively defined only in terms of a serum total IgE level above $100 \mathrm{IU} / \mathrm{ml}$, in order to see the effect of a different definition on the results of a linkage and an association analysis.

\section{ANALYSIS OF GENOTYPE}

Total genomic DNA was extracted from peripheral blood by phenol/chloroform extraction followed by ethanol precipitation. ${ }^{17}$ To determine genotypes at D11S97, a variable number of tandem repeat (VNTR) regions on chromosome 11q13, $5 \mu \mathrm{g}$ DNA were digested with PstI, separated by electrophoresis on a $1.0 \%$ agarose gel, and transferred to a nylon membrane (Hybond $\mathrm{N}^{+}$, Amersham, UK) by Southern blotting. The radiolabelled cDNA probe D11S97 produced eight alleles with the sizes ranging from $0.96 \mathrm{~kb}$ to $2.9 \mathrm{~kb}$. To determine genotypes at the FceRI $\beta$ locus, $100 \mathrm{ng}$ DNA was used as template for the polymerase chain reaction (PCR). Primers for sequences flanking the $\mathrm{CA} / \mathrm{GT}$ repeat region in the fifth intron of the FceRI $\beta$ gene were used at a concentration of $0.5 \mu \mathrm{mol} / 1$ each, one primer being end labelled with ${ }^{32} \mathrm{P} .{ }^{17}$ Conditions for PCR were: initial denaturation for five minutes at $95^{\circ} \mathrm{C}$ followed by 25 cycles at $95^{\circ} \mathrm{C}$ for 60 seconds, $60^{\circ} \mathrm{C}$ for 60 seconds, and $72^{\circ} \mathrm{C}$ for 90 seconds with a final extension of $72^{\circ} \mathrm{C}$ for five minutes. An equal volume of sequencing gel loading buffer (98\% formamide, $0.05 \%$ bromophenol blue, $0.05 \%$ xylene cyanol, and $20 \mathrm{mmol} / 1 \mathrm{EDTA}$ ) was added to the PCR product. A total of $2 \mu \mathrm{l}$ of this mixture was loaded on $5 \%$ polyacrylamide gel, and the autoradiographs were read after being exposed overnight. Eight alleles were detected in the CA/ GT microsatellite region of the $\mathrm{Fc} \varepsilon \mathrm{RI} \beta$ gene in the 107 family members.

\section{ASSOCIATION ANALYSIS}

Differences between frequencies of the VNTR alleles of D11S97 and the CA/GT microsatellite alleles of the $\mathrm{Fc} \varepsilon \mathrm{RI} \beta$ gene within normal chromosomes and those within atopic chromosomes were examined in the 107 subjects from the 14 unrelated families. Association of serum total IgE levels with the D11S97/Pst $0.96 \mathrm{~kb}$ allele was also examined in the 120 unrelated Japanese subjects. These were examined by a $\chi^{2}$ test, using the SPSS statistical program. An odds ratio and its $95 \%$ confidence interval $(95 \% \mathrm{CI})$ were calculated as a measure of the strength of association.

\section{PARAMETRIC LINKAGE ANALYSIS}

The segregation pattern of atopy and high total IgE level was examined using the Davie's singles method. ${ }^{18}$ Multipoint linkage analysis of atopy on chromosome 11q13 was computed for a maternal inheritance model using the LINKMAP subroutine of the computer program LINKAGE (version 5.1).

We divided seven three generation families into 26 nuclear families, and analysed a total of 33 nuclear families using a three liability class model following the Oxford group's method. ${ }^{9}$ In order to assume maternal inheritance, all fathers were considered pheno- 

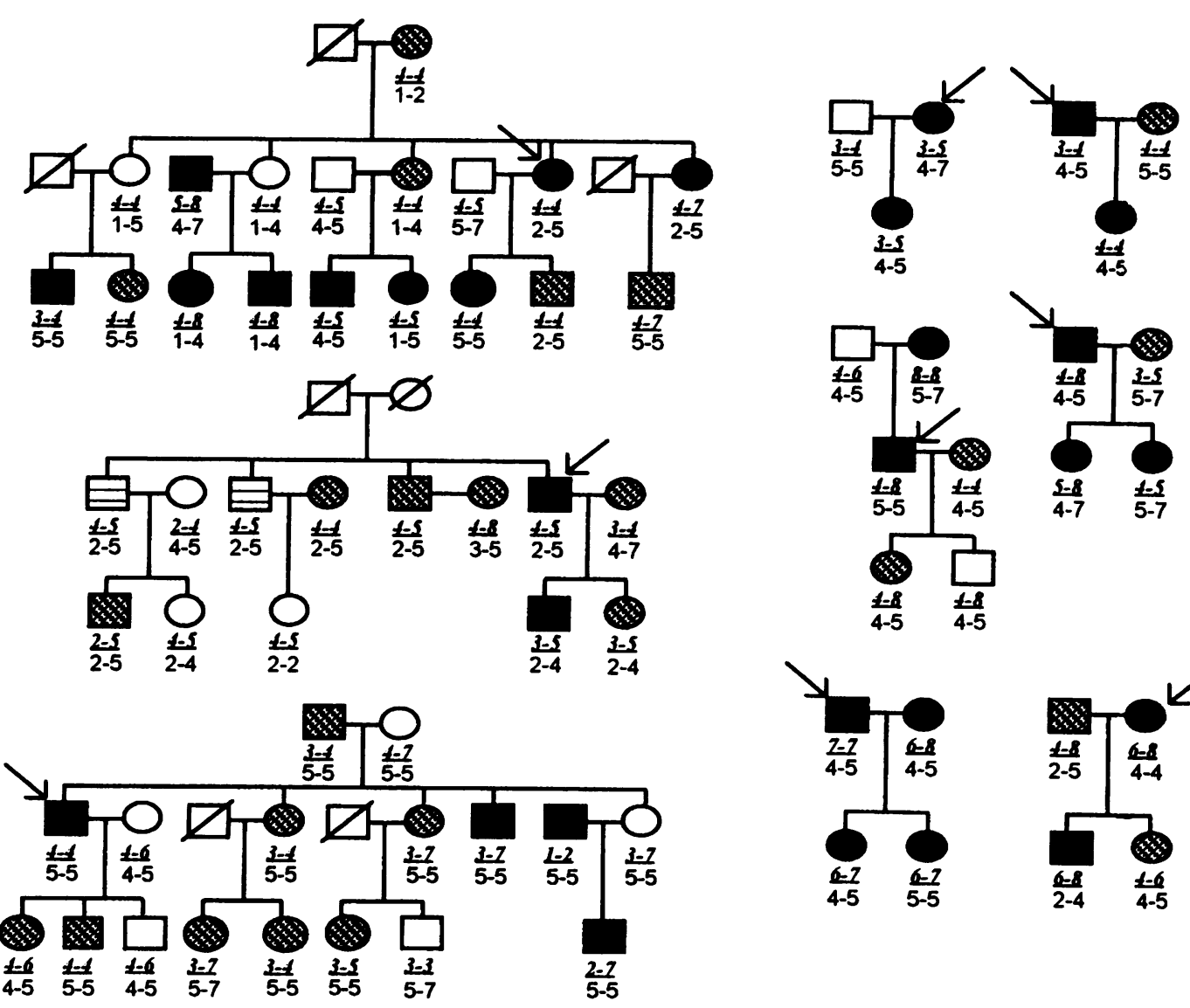

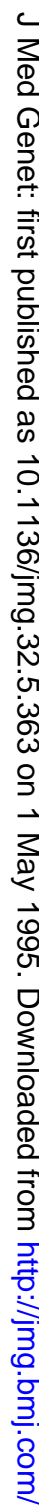
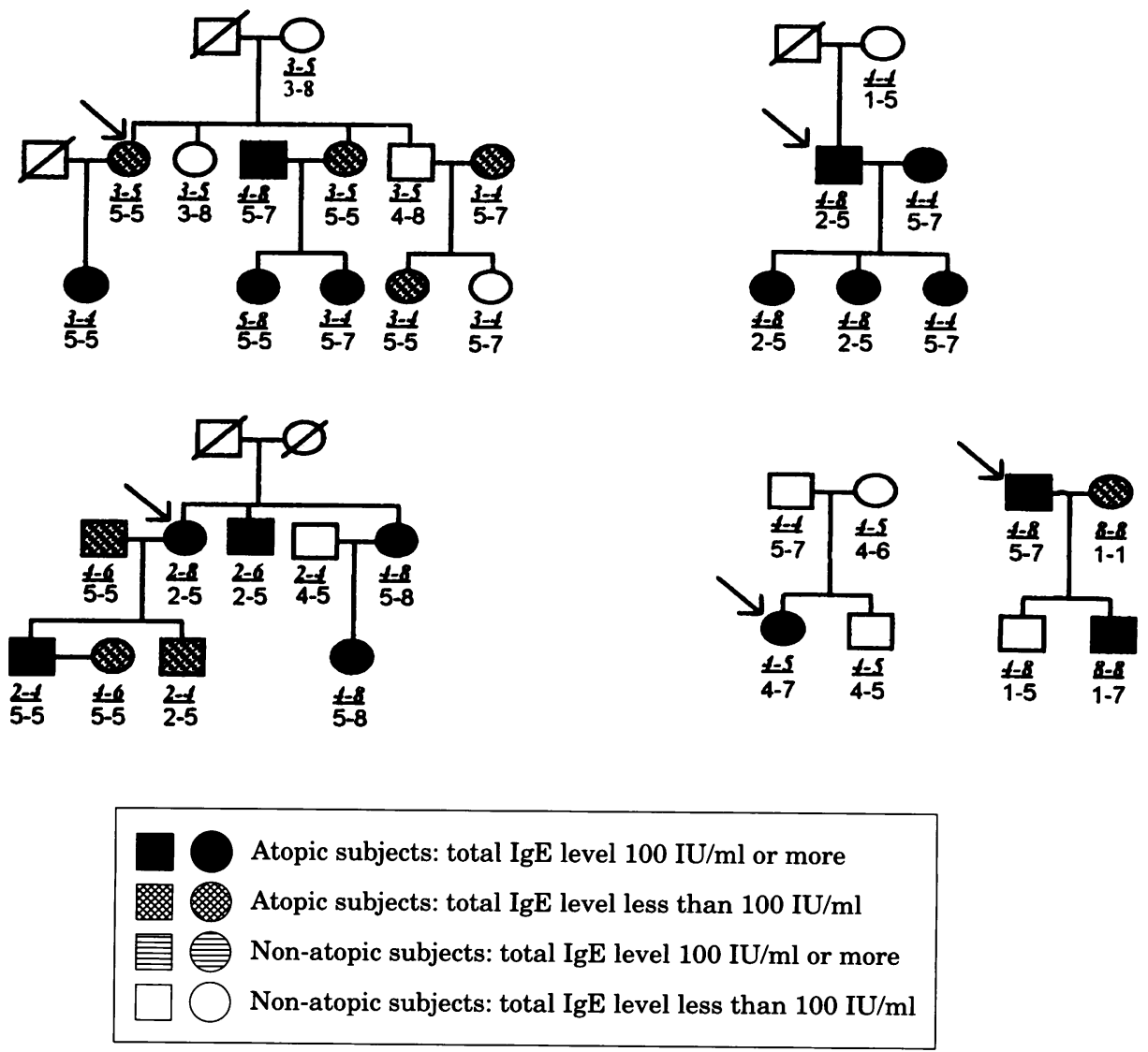

Figure 1 Pedigree data. Atopic status was determined by any or all of a positive skin prick test or a high antigen specific IgE value or a high total IgE level $(>=300 \mathrm{IU} / \mathrm{ml}) . \mathrm{N}-\mathrm{N}, \mathrm{N}-\mathrm{N}=$ genotypes of D11S97 and FcERI $\beta$ respectively. The numerical assignment of each allele was determined according to their sizes. D11S97/PstI 0.96 kb allele was assigned to 8 . The atopic probands are indicated by arrows. 
Table 1 Association between atopy and D11S97 locus

(A) Atopy (high total IgE levels/positive skin test/raised MAST score)

\begin{tabular}{lcc}
\hline D11S97/PstI allele & $\begin{array}{l}\text { Atopy } \\
\text { chrmosomes }\end{array}$ & $\begin{array}{l}\text { Normal } \\
\text { chromosomes }\end{array}$ \\
\hline $1(2 \cdot 9 \mathrm{~kb})$ & $1(0 \cdot 5)$ & $0(0 \cdot 0)$ \\
$2(2 \cdot 6 \mathrm{~kb})$ & $7(4 \cdot 4)$ & $2(3 \cdot 7)$ \\
$3(2 \cdot 4 \mathrm{~kb})$ & $21(13 \cdot 1)$ & $8(14 \cdot 8)$ \\
$4(2 \cdot 1 \mathrm{~kb})$ & $66(41 \cdot 3)$ & $26(48 \cdot 1)$ \\
$5(1.9 \mathrm{~kb})$ & $18(11 \cdot 3)$ & $11(20 \cdot 4)$ \\
$6(1.2 \mathrm{~kb})$ & $10(6 \cdot 3)$ & $3(5 \cdot 6)$ \\
$7(1.06 \mathrm{~kb})$ & $10(6 \cdot 3)$ & $2(3 \cdot 7)$ \\
$8(0.96 \mathrm{~kb})$ & $27(16 \cdot 8)$ & $2(3 \cdot 7)$ \\
\hline$\chi^{2}=9 \cdot 1, \mathrm{p}=0 \cdot 25$. & &
\end{tabular}

(B) High serum total IgE levels

\begin{tabular}{lcc}
\hline D11S97/PstI allele & $\begin{array}{l}\text { High IgE } \\
\text { chromosomes }\end{array}$ & $\begin{array}{l}\text { Low IgE } \\
\text { chromosomes }\end{array}$ \\
\hline $1(2.9 \mathrm{~kb})$ & $1(1 \cdot 0)$ & $0(0 \cdot 0)$ \\
$2(2.6 \mathrm{~kb})$ & $5(5 \cdot 1)$ & $4(3 \cdot 5)$ \\
$3(2 \cdot 4 \mathrm{~kb})$ & $8(8 \cdot 2)$ & $21(18 \cdot 1)$ \\
$4(2 \cdot 1 \mathrm{~kb})$ & $36(36 \cdot 7)$ & $56(48 \cdot 3)$ \\
$5(1.9 \mathrm{~kb})$ & $13(13 \cdot 3)$ & $16(13 \cdot 8)$ \\
$6(1.2 \mathrm{~kb})$ & $6(6 \cdot 1)$ & $7(6 \cdot 0)$ \\
$7(1.06 \mathrm{~kb})$ & $7(7 \cdot 1)$ & $5(4 \cdot 3)$ \\
$8(0.96 \mathrm{~kb})$ & $22(22 \cdot 5)$ & $7(6 \cdot 0)$ \\
\hline
\end{tabular}

$\chi^{2}=18 \cdot 4, \mathrm{p}=0 \cdot 01$.

Figures in parentheses are percentages.

There was statistically significant evidence of an association between the D11S97 locus and the high total IgE levels $(>=$ $100 \mathrm{IU} / \mathrm{ml}$ )

In particular, a higher frequency of the D11S97/PstI $0.96 \mathrm{~kb}$ allele was noted in the subjects with high total IgE levels.

typically normal within the first class. Mothers and their offspring were placed in the second and third classes, respectively. Penetrance for homozygotes was set at 1.0 in all classes and that for heterozygotes was set at $1 \cdot 0,0 \cdot 6$, and 0.98 in the first, second, and third classes, respectively.

The gene frequency for the disease allele was assumed to be $0 \cdot 25$. The genetic distance was calculated from the recombination fraction using the Kosambi mapping function. ${ }^{19}$

\section{NON-PARAMETRIC LINKAGE ANALYSIS}

Linkage of atopy or high serum IgE levels to chromosome $11 \mathrm{q} 13$ was also tested by the affected pedigree member method. ${ }^{1314}$ This analysis made no explicit assumptions about the mode of inheritance, genotype penetrance, or the presence of phenocopies. The program Apm (version 2.0), Sim, and Apmult were used and the allele frequencies for D11S97 and FceRI $\beta$ were calculated from the allele frequencies in the 120 unrelated Japanese subjects.

\section{SCREENING FOR THE LEU181 SUBSTITUTION}

To detect the point mutation in the sixth exon, which is responsible for the Leul81 substitution in the fourth transmembrane domain of FceRI $\beta$, the amplification refractory muta-

Table 2 Association of high serum IgE levels with the D11S97/PstI $0.96 \mathrm{~kb}$ allele

\begin{tabular}{llllll}
\hline & $\begin{array}{l}\text { High IgE } \\
\text { chromosomes }\end{array}$ & $\begin{array}{l}\text { Low IgE } \\
\text { chromosomes }\end{array}$ & Odds ratio & $95 \%$ CI & p value \\
\hline $\begin{array}{l}\text { Family study } \\
\begin{array}{l}\text { Population } \\
\text { study }\end{array}\end{array}$ & $21 / 98(21 \cdot 4)$ & $7 / 116(6.0)$ & 4.25 & $1.72-10.5$ & 0.0008 \\
\hline & $25 / 134(17 \cdot 9)$ & $5 / 106(4 \cdot 7)$ & 4.4 & $1.62-11.9$ & 0.019 \\
\hline
\end{tabular}

The frequency of the D11S97/PstI $0.96 \mathrm{~kb}$ allele was significantly increased in the high IgE chromosomes in both family and population studies.

Figures in parentheses are percentages. tion system (ARMS) was applied under the same conditions as established by the Oxford group. ${ }^{10}$ Normal and mutant specific oligonucleotide primers for Leu181 of Fc\&RI $\beta$ and a control pair of primers for HLA-DP were prepared with a model 380A DNA synthesiser (Applied Biosystems Inc). The amplified products of the ARMS reaction were stained with ethidium bromide after electrophoresis on a $4 \%$ agarose gel.

In a subject who had no Leu181 substitution on the ARMS test, the DNA sequence of the sixth exon of FceRI $\beta$ was also analysed by the fluorescence based dideoxy sequence method with a model 373A automated DNA sequencer (Applied Biosystems Inc) to confirm the accuracy of this test.

\section{Results}

FAMILY STUDY

Eighty subjects were atopic out of the 107 subjects from the 14 Japanese families. Seventyeight subjects had high antigen specific IgE responses detected by the skin prick test or MAST. Forty-nine subjects had a total IgE level higher than or equal to $100 \mathrm{IU} / \mathrm{ml}$. Two subjects were assigned as atopic only by a high serum total IgE level. Although an association between atopy (a positive skin test/a high total IgE level/a high antigen specific IgE value) and D11S97 was not found (table 1A), the distribution of the D11S97 allele differed significantly between the chromosomes of the subjects with and without high serum IgE levels $\left(\chi^{2}=18.4, p=0.01\right)$ (table 1B). In particular, a higher frequency of the D11S97/PstI $0.96 \mathrm{~kb}$ allele was noted in the subjects with high total IgE levels (table 2). None of the subjects with a D11S97/PstI $0.96 \mathrm{~kb}$ allele had a total IgE level lower than or equal to $10 \mathrm{IU} / \mathrm{ml}$ (fig $2 \mathrm{~A}$ ). The mean level of the serum total IgE was 782 (SE 259) $\mathrm{IU} / \mathrm{ml}$ for the subjects with this allele and 381 (SE 119) IU/ml for the subjects without this allele. However, we could not find any association between atopy or high total IgE levels and the FceRI $\beta$.

Segregation of both atopy and high total serum IgE levels occurred vertically (fig 1) and the ratio of atopic children to all children from marriages with a single atopic parent were 0.79 (SE 0.1) and 0.54 (SE 0.1) respectively, calculated by Davie's singles method. As the putative atopy gene is not necessarily lethal to homozygotes, these segregation patterns were not discordant with the assumption of dominant inheritance. ${ }^{3}$

The maximum lod score between the D11S97 locus and the FceRI $\beta$ locus was 3.0 at a recombination fraction of 0.15 in the 14 unrelated Japanese families. Multipoint linkage analyses were done with these two informative markers on chromosome 11q13. Using the same genetic model of maternal inheritance that the Oxford group presented, ${ }^{9}$ evidence for linkage was not observed between atopy underlying asthma and the chromosome 11q13 region with location scores to - 35 (fig 3). Even when atopic status was assigned only by serum total IgE levels, the location score 

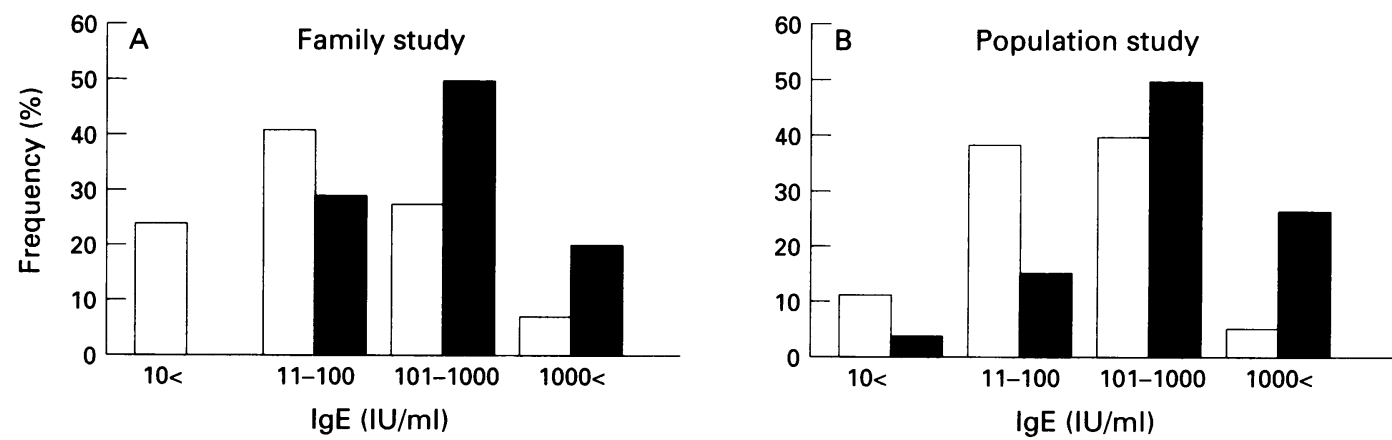

Subjects without D11S97/Pst1 $0.96 \mathrm{~kb}$ allele Subjects with D11S97/Pstl $0.96 \mathrm{~kb}$ allele

Figure 2 The distribution of serum total IgE levels in the subjects studied. The frequency distributions divided into four ranges according to total $I g E$ levels are presented for subjects with D11S97/PstI $0.96 \mathrm{~kb}$ allele and for subjects without this allele in the family study $(A)$ and in the population study $(B)$.

increased to -14 and we could not support the linkage of atopy to chromosome $11 \mathrm{q} 13$ under these conditions (fig 3). Varying the gene frequency between $15 \%$ and $35 \%$ had little effect on these results. Also, varying class 2

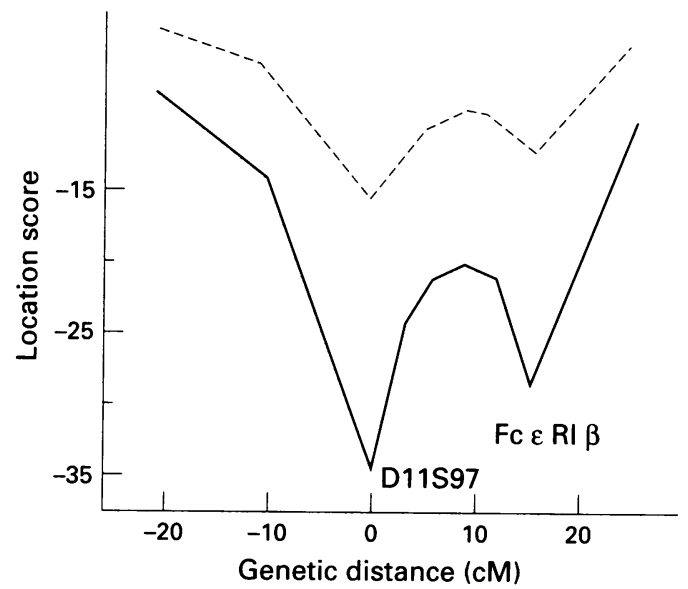

\section{- Atopy \\ -.- High total IgE}

Figure 3 Multipoint linkage analysis between atopy and markers on chromosome 11q13. Linkage analysis was computed for the maternal inheritance model. Solid line: atopic status was assigned according to a total IgE level, an antigen specific IgE value, and the response to a skin an antigen specific IgE value, and the response to a skin
prick test. Dotted line: atopic status was assigned only by a total IgE level (>100 IUlml).

Table 3 Analysis of linkage by affected pedigree member method

(A) Atopy (high total IgE levels/positive skin test/raised MAST score)

\begin{tabular}{|c|c|c|c|c|}
\hline Locus & D11S97 & & $F_{c \varepsilon R I} \beta$ & \\
\hline Weight & $t$ statistic & p value & $t$ statistic & $p$ value \\
\hline $\begin{array}{l}\mathrm{f}(\mathrm{p})=1 \\
\mathrm{f}(\mathrm{p})=1 / \mathrm{p}^{1 / 2} \\
\mathrm{f}(\mathrm{p})=1 / \mathrm{p}\end{array}$ & $\begin{array}{r}-0.95 \\
-0.23 \\
0.78\end{array}$ & $\begin{array}{l}0.83 \\
0.59 \\
0 \cdot 21\end{array}$ & $\begin{array}{r}0.82 \\
0.54 \\
-0.29\end{array}$ & $\begin{array}{l}0 \cdot 2 \\
0 \cdot 29 \\
0 \cdot 62\end{array}$ \\
\hline
\end{tabular}

(B) High serum total IgE levels

\begin{tabular}{|c|c|c|c|c|}
\hline Locus & D11S97 & & $F_{c \varepsilon R I} \beta$ & \\
\hline Weight & $t$ statistic & $p$ value & $t$ statistic & p value \\
\hline $\begin{array}{l}f(p)=1 \\
f(p)=1 / p^{1 / 2} \\
f(p)=1 / p\end{array}$ & $\begin{array}{l}-1 \cdot 6 \\
-1.02 \\
0.22\end{array}$ & $\begin{array}{l}0.95 \\
0.85 \\
0.41\end{array}$ & $\begin{array}{r}0.45 \\
0.15 \\
-0.26\end{array}$ & $\begin{array}{l}0.33 \\
0.44 \\
0.6\end{array}$ \\
\hline
\end{tabular}

$\mathrm{p}$ denotes the frequency of shared marker alleles. penetrance for heterozygotes between $50 \%$ and $70 \%$ with class 3 penetrance fixed at $98 \%$ had no effect on the results at all, and reducing class 3 penetrance for heterozygotes from $98 \%$ to $80 \%$ with class 2 penetrance fixed at $60 \%$ increased the maximum location score only to -20 .

The affected pedigree member method also showed no evidence that either D11S97 or FceRI $\beta$ was linked to atopy or high total serum IgE levels (table 3A,B). The multilocus affected pedigree member method using the Apmult program also showed a $t$ statistic of 0.24 and a $p$ value of $0 \cdot 4$ for $f(p)=1 / p^{1 / 2}$.

POPULATION STUDY

The mean level of serum total IgE of the subjects with the D11S97/PstI $0.96 \mathrm{~kb}$ allele was 1314 (SE 438) IU/ml and that of the subjects without this allele was 390 (SE 99) IU/ml. The frequency of this allele significantly increased in the chromosomes of the subjects with high total serum IgE levels $\left(\chi^{2}=9 \cdot 7, \mathrm{p}=0.019\right)$ (table 2). The total IgE level showed unimodal distribution both in the subjects with and without the $0.96 \mathrm{~kb}$ allele (fig $2 \mathrm{~B}$ ).

Although age, sex, smoking habits, and a personal history of asthma are said to affect the level of serum total $\operatorname{IgE},{ }^{20}$ there were no significant differences in these characteristics between the subjects with the $0.96 \mathrm{~kb}$ allele and the subjects without this allele both in the family and in the population study (table 4 ).

THE ARMS TEST FOR LEU181 SUBSTITUTION

All DNA samples from the 107 subjects from 14 atopic families and 120 unrelated Japanese subjects failed to amplify when incubated with a pair of oligonucleotide primers specific for the Leu181 substitution. DNA sequence analysis showed a homozygote of wild type sequence at the junction of the fifth intron and sixth exon of FceRI $\beta$ (data not shown) in a subject without the Leu181 substitution on the ARMS test, which verified the results of the ARMS method. 
Table 4 Characteristics of the subjects in the studies

(A) Family study

\begin{tabular}{llll}
\hline & D11S97/PstI $0.96 \mathrm{~kb}(+)$ & D11S97/PstI $0.96 \mathrm{~kb}(-)$ & $p$ \\
\hline No & 26 & 81 & \\
Mean age (SE) & $36 \cdot 2(3 \cdot 7)$ & $36 \cdot 8(2 \cdot 0)$ & NS \\
Current smokers (\%) & 36 & 34 & NS \\
Sex (female/male) & $-15 / 10$ & $47 / 32$ & NS \\
Asthmatic subjects (\%) & 46 & 32 & NS \\
\hline
\end{tabular}

(B) Population study

\begin{tabular}{llll}
\hline & D11S97/PstI $0.96 k b(+)$ & D11S97/PstI $0.96 k b(-)$ & $p$ \\
\hline No & 25 & 95 & \\
Mean age (SE) & $44(3)$ & $42(1)$ & NS \\
Current smokers (\%) & 48 & 30 & NS \\
Sex (female/male) & $.14 / 11$ & $42 / 53$ & NS \\
Asthmatic subjects (\%) & 60 & 51 & NS \\
\hline
\end{tabular}

Statistical significance ( $p$ value) was calculated by a Mann-Whitney test for comparison of age and by a $\chi^{2}$ test for comparisons of the frequency of current smokers, sex, and the proportion of asthmatic subjects. the absence of linkage between atopy/high serum IgE levels and chromosome $11 \mathrm{q} 13$.

In most complex diseases such as atopic diseases, it might be more straightforward to look for an association between DNA polymorphisms and disease. ${ }^{1115}$ Association studies have proved to be particularly useful in atopic diseases in which certain MHC alleles are directly involved in highly purified allergen specific immune responsiveness. ${ }^{1}$ Also, if a major gene is only responsible for a minority of atopy, association study will offer a promising tool to identify the susceptibility gene. In our study of 14 Japanese families we observed an association between high serum total IgE levels and the D11S97/PstI $0.96 \mathrm{~kb}$ allele. To confirm this relationship, we further examined 120 unrelated Japanese subjects and again detected a significant association between them in the population study.

As it is unlikely that the polymorphic VNTR DNA markers themselves contribute to the pathogenesis of atopy, the finding of a significant association between high serum total IgE levels and D11S97 in Japanese subjects can be interpreted in terms of linkage disequilibrium.

The distribution of the $\operatorname{IgE}$ level broadly overlapped between the subjects with and without the D11S97/PstI $0.96 \mathrm{~kb}$ allele, both in the family study and in the population study (fig 2). Accordingly, we suspect that a gene close to the D11S97 locus could modify clinical expression but is neither a necessary nor a sufficient cause of atopy, and that its effect is not as major as the linkage analysis could detect. In fact, although several studies have indicated that the total IgE level is regulated by a major gene irrespective of whether high levels are the result of dominant or recessive alleles, there also appeared to be significant polygenic influences. ${ }^{1212224}$

A computer simulation study indicated that if the probability of having the disease with the associated allele is less than 10 times greater than the probability of having the disease without the allele, then it may be difficult to detect linkage. ${ }^{25}$ Our failure to find linkage when an association exists, or even finding significant evidence against linkage, may indicate that a gene or genes on chromosome $11 \mathrm{q} 13$, in the Japanese population, is not necessary for expression of atopy and is merely a susceptibility gene; this point is different from the Oxford group's hypothesis of a major necessary gene for atopy at $11 \mathrm{q} 13$.

The linkage analysis of atopy underlying atopic eczema to the chromosome 11 q13 region excluded a major gene for atopy in the British population study. ${ }^{26}$ Affected sib pairs analysis found neither a significantly increased proportion of shared alleles at the FceRI $\beta$ locus nor a significant difference in the proportion of maternal alleles shared at the D11S97 locus. ${ }^{27}$ These reports, including our own study, suggest that there is genetic heterogeneity in atopy, and that the atopy gene proposed by the Oxford group, which has a major effect on atopic phenotype and is located close to FceRI $\beta$ locus, may not be a prevalent one. Absence of a of atopy to chromosome 11q13 was not only the result of an incorrect genetic model of atopy, but also that the results of the affected pedigree member method further strengthened 
mutation responsible for the Leu181 substitution in the Japanese atopic subjects further suggested the heterogeneity of the genetic regulation of serum total IgE levels between the Japanese and British populations.

In conclusion, in spite of our failure to confirm genetic linkage between atopy and chromosome $11 \mathrm{q} 13$, even under the model of maternal inheritance, the association detected both in the 107 subjects belonging to the 14 families and in the 120 unrelated Japanese subjects indicated the presence of a susceptibility gene for the high IgE responsiveness at chromosome 11q13, as in the British population, interacting with several major or minor genes responsible for the expression of atopy. In order to define the exact nature of the association in the Japanese population, the chromosome $11 \mathrm{q} 13$ region needs further evaluation for the presence of a gene or genes regulating atopy or high $\operatorname{IgE}$ responsiveness.

We are grateful to Dr A Wakisaka, associate professor of the First Department of Pathology, Hokkaido University for his advice on performing the linkage analysis using the LINKAGE program and to Ms S Yuhki for her technical assistance. We also thank Dr W O C M Cookson at John Radcliffe Hospital, Oxford for his kind suggestions on the linkage analysis under the model of a maternal inheritance.

1 Marsh DG, Meyers DA, Bias WB. The epidemiology and genetics of atopic allergy. N Engl f Med 1981;305:1551-9. Cookson WOCM, Sharp PA, Faux JA, Hopkin JM. Linkage Cookson WOCM, Sharp PA, Faux JA, Hopkin JM. Linkage
between immunoglobulin E responses underlying asthma between immunoglobulin E responses underlying asthma
and rhinitis and chromosome 11 q. Lancet 1989;i:1292-5.

3 Hizawa N, Yamaguchi E, Ohe M, et al. Lack of linkage Hizawa N, Yamaguchi E, Ohe M, et al. Lack of linkage
between atopy and locus 11q13. Clin Exp Allergy 1992; between atopy

4 Rich SS, Roitman-Johnson B, Greenberg B, Roberts S, Blumenthal MN. Genetic analysis of atopy in three large kindreds: no evidence of linkage to D11S97. Clin Exp Allergy 1992;22:1070-6.

5 Amelung PJ, Panhuysen CIM, Postma DS, et al. Atopy and bronchial hyperresponsiveness: exclusion of linkage to markers on chromosomes 11q and 6p. Clin Exp Allergy 1992;22:1077-84.

6 Lympany P, Welsh KI, Cochrane GM, Kemeny DM, Lee TH. Genetic analysis of the linkage between chromosome $11 \mathrm{q}$ and atopy. Clin Exp Allergy 1992;22:1085-92.
7 Marsh DG, Neely JD, Breazeale DR, et al. Linkage analysis of IL4 and other chromosome 5q31.1 markers and total serum immunoglobulin E concentrations. Science 1994; 264:1152-6.

8 Cookson WOCM, Young RP, Sandford AJ, et al. Maternal inheritance of atopic IgE responsiveness on chromosome 11q. Lancet 1992;340:381-4.

9 Sandford AJ, Shirakawa T, Moffatt MF, et al. Localisation of atopy and $\beta$ subunit of high-affinity IgE receptor ( $F c \varepsilon R I)$ on chromosome 11 q. Lancet 1993;341:332-4.

10 Shirakawa T, Li A, Dubowitz M, et al. Association between atopy and variants of the $\beta$ subunit of the high-affinity atopy and variants of the $\beta$ subunit of the high-affinity

11 Owen MJ, McGuffin P. Association and linkage: plementary strategies for complex disorders. $\mathcal{F}$ Med Genet 1994;30:638-9.

12 Risch N. Genetic linkage: interpreting lod scores. Science 1992;255:803-4.

13 Weeks DE, Lange $K$. The affected-pedigree-member method of linkage analysis. Am $\mathcal{F}$ Hum Genet 1988;42: meth-26.

14 Weeks DE, Lange K. A multilocus extension of the affectedpedigree-member method of linkage analysis. Am $\mathcal{F} \mathrm{Hum}$ Genet 1992;50:859-68.

15 Nothen MM, Propping P, Fimmers R. Association versus linkage studies in psychosis genetics. $\mathcal{F}$ Med Genet 1992; 30:634-7.

16 Brown CR, Higgins KW, Frazer K, et al. Simultaneous determination of total IgE and allergen-specific IgE in serum by the MAST chemiluminescent assay system. Clin Chem 1985;31:1500-5.

17 Maniatis TM, Fritsch EF, Sambrook J. Molecular cloning. A laboratory manual. Cold Spring Harbor, NY: Cold Spring Harbor Laboratory Press, 1989.

18 Davie AM. The 'singles' method for segregation analysis under incomplete ascertainment. Ann Hum Genet 1979; 42:507-12.

19 Ott J. Analysis of human genetic linkage. Baltimore: The Johns Hopkins University Press, 1985.

20 Criqui MH, Seibles J, Hamburger RN, Coughlin SS, Gabriel $\mathrm{S}$. Epidemiology of immunoglobulin $\mathrm{E}$ levels in a defined population. Ann Allergy 1990;64:308-13.

21 Blumenthal MN, Amos DB. Genetic and immunologic basis of atopic responses. Chest 1987;91:176S-84S.

22 Borecki IB, Rao DC, Lalouel JM, McGue M, Gerrard JW. Demonstration of a common major gene with pleiotrophic Demonstration of a common major gene with pleiotrophic
effects on immunoglobulin $\mathrm{E}$ levels and allergy. Genet Epidemiol 1985;2:327-38.

23 Marsh DG, Meyers DA. A major gene for allergy-fact or fancy? Nature Genet 1992;2:252-4.

24 Meyers DA, Beaty TH, Freidhoff LR, Marsh DG. InMeyers DA, Beaty TH, Freidhoff LR, Marsh DG. In-
heritance of total serum IgE (basal levels) in man. Am f Hum Genet 1987;41:51-62.

25 Greenberg DG. Linkage analysis of "necessary" disease loci versus "susceptibility" loci. Am f Hum Genet 1993;52: 135-43.

26 Coleman R, Trembath RC, Harper JI. Chromosome 11q13 and atopy underlying atopic eczema. Lancet 1993;341: $1121-2$

27 Collee JM, ten Kate LP, de Vries HG, et al. Allele sharing on chromosome $11 \mathrm{q} 13$ in sibs with asthma and atopy. Lancet 1993;342:936. 